\title{
The Prognostic Factors on Survival Rates for Patients with Stage II-III Colon Cancer
}

\section{Evre 2-3 Kolon Kanserli Hastaların Sağkalım Oranlarını Etkileyen Prognostik Faktörler}

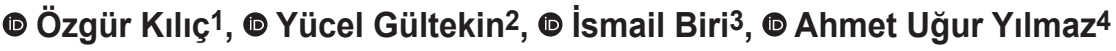 \\ 1Siyami Ersek Thoracic and Cardiovascular Surgery Training and Research Hospital, Clinic of Intensive Care, İstanbul, Turkey \\ 2Mersin University Faculty of Medicine, Department of General Surgery, Division of Gastroenterology Surgery, Mersin, Turkey \\ ${ }^{3}$ Ankara Koru Hospital, Clinic of General Surgery, Ankara, Turkey \\ 4 İzmir University Faculty of Medicine, Department of Medical Oncology, İzmir, Turkey
}

\section{HIIIIII ABSTRACT}

Aim: A substantial portion of colon cancer is diagnosed at stage II or III. While high survival rates are obtained with curative surgery in stage I, conversely, in stage IV curative surgery has no place, and survival rates are significantly lower despite chemotherapy. Survival rates vary greatly in stage II and III colon tumors, which are treated with combination of curative surgery and chemoterapy. This study aimed to analyse the prognostic factors on survival of stage II-III colon cancers.

Method: One hundred seventy four patients with stage II or III colon cancer in the follow-up of Dokuz Eylül University Faculty of Medicine Oncology Clinic between January 1999 and August 2010 were included in the study. Prognostic factors defined in the literature were investigated retrospectively in this patient population. The factors that were found to be significant according to the univariate analysis were evaluated by multivariate analysis and independent factors were found.

Results: In univariate analysis, presence of obstruction or perforation at admission, preoperative high carcinoembryonic antigen level, presence of lymphatic invasion (LI) and inadequate number of total lymph nodes removed were the poor prognostic indicators for disease-free survival. Of these, the presence of obstruction or perforation at admission was the only independent prognostic factor in multivariate analysis. Inadequate number of total lymph nodes removed and presence of LI were found to be associated with decreased overall survival in both univariate and multivariate analyzes. Conclusion: Presence of obstruction or perforation at admission, inadequate number of total lymph nodes removed and the presence of LI were associated with poor prognosis in patients with stage II and III colon cancer.

Keywords: Colon cancer, prognostic factor, survival

\section{|HIIIIII| ÖZ}

Amaç: Kolon kanserinin önemli bir kısmı evre 2 veya 3'te tanı alır. Evre l'de küratif cerrahi ile yüksek sağkalım sonuçları sağlanırken, tersine evre 4'te küratif cerrahinin yeri olmadığı gibi kemoterapiye rağmen sağkalım oranları oldukça düşüktür. Küratif cerrahi ve kemoterapi kombinasyonu ile tedavi edilen evre 2 ve 3’te ise sağkalım oranları büyük değişkenlik gösterir. Bu çalışmanın amacı evre 2-3 kolon kanserlerinde sağkalımı etkileyen prognostik faktörleri araştırmak idi.

Yöntem: Ocak 1999 ve Ağustos 2010 arasında Dokuz Eylül Üniversitesi Tıp Fakültesi Onkoloji Kliniği’nin takibindeki evre 2 veya 3 kolon kanserli 174 hasta çalışmaya alındı. Literatürde tanımlanmış prognostik faktörler bu hasta grubunda retrospektif olarak incelendi. Tek değişkenli analizde anlamlı bulunan faktörler çok değişkenli analize alındı ve bağımsız prognostik faktörler bulundu.

Bulgular: Tek değişkenli analizde, başvuru sırasında obstrüksiyon veya perforasyon varlığı, preoperatif yüksek karsinoembriyonik antijen seviyesi, lenfatik invazyon (Lì) varlığı ve yetersiz çıkarılan toplam lenf nodu sayısı, hastalıksız sağkalımı etkileyen kötü prognostik göstergelerdi. Bunlardan, sadece başvuru sırasında tıkanma veya perforasyon varlı̆̆ı, çok değişkenli analizde bağımsız prognostik faktör olarak belirlenmiştir. Yetersiz çıkarılan toplam lenf nodu sayısı ve Lİ varlığı, hem tek değişkenli hem de çok değişkenli analizlerde genel sağkalımın azalması ile ilişkili bulundu.

Our article was presented at the $17^{\text {th }}$ Turkish Colon and Rectum Surgery Congress as an oral notification in 2019.

Address for Correspondence/Yazışma Adresi: Yücel Gültekin, MD,

Mersin University Faculty of Medicine, Department of General Surgery, Division of Gastroenterology Surgery, Mersin, Turkey

E-mail: dryc168@hotmail.com ORCID ID: orcid.org/0000-0002-1974-1242

Received/Geliş Tarihi: 14.03.2020 Accepted/Kabul Tarihi: 18.12.2020

${ }^{\circ}$ Copyright 2021 by Turkish Society of Colon and Rectal Surgery

Turkish Journal of Colorectal Disease published by Galenos Publishing House. 
Sonuç: Başvuru sırasında obstrüksiyon veya perforasyon varlığı, çıkarılan total lenf nodu yetersizliği ve Lİ varlı̆̆ı evre 2 ve 3 kolon kanseri olan hastalarda kötü prognoz ile ilişkili bulunmuştur.

Anahtar Kelimeler: Kolon kanseri, prognostik faktör, sağkalım

\section{Introduction}

According to the current data of the World Health Organization, colon cancers are the third most common malignancy worldwide. ${ }^{1}$ The incidence of colon cancer is almost equal in both men and women. Advanced age and family history are major risk factors for colon cancer. Genetic syndromes such as familial adenomatosis polyposis and hereditary non-polyposis colorectal cancer constitute $2 \%$ $4 \%$ of the cases. ${ }^{2}$ Approximately $10 \%$ of patients with colon cancer have a family history without genetic predisposition. ${ }^{3}$ Other risk factors include low fibre, high fat diet, obesity and physical inactivity. ${ }^{4}$

Colon cancer, when diagnosed at an early stage, has minimal morbidity and mortality as it is a curable malignancy when managed with appropriate surgical intervention. ${ }^{5}$ While survival rates in stage 1 tumours reach $93 \%$ with curative surgery, the chance of surgery is eliminated in stage 4 tumours, but this rate decreases to $8 \%$ despite chemotherapy. The situation is quite different in stage 2 and stage 3 tumours, which are grouped as locally advanced colon cancer. In these cancers, survival rates vary between $64 \%$ and $78 \%$ with the combination of curative surgery and chemotherapy. ${ }^{5}$ However, after curative surgical resection, some patients may have recurrent distant metastases, which accounted for $25 \%$ and $50 \%-60 \%$ in 5 years for stage II and stage III colon cancers, respectively. ${ }^{2}$ The risk of recurrence can be estimated based on the clinical and histological characteristics of the cancer. The risk increases with high stage, elevated level of preoperative carcinoembryonic antigen (CEA), inadequate number of lymph nodes removed and obstruction or perforation at admission. Metastasis to regional lymph nodes is the most powerful factor in predicting whether the disease will benefit from surgical resection..$^{6,7,8}$

This study aimed to investigate the prognostic factors affecting disease-free and overall survival (OS) in patients with stage II and III colon cancers who underwent curative surgical resection.

\section{Method}

This cohort study included patients with stage II and III colon cancers who received follow-up treatment at Dokuz Eylül University Faculty of Medicine Medical Oncology Institute from January 1999 to August 2010. Patients aged $<18$ years, patients with stage I and IV colon cancers as well as patients with rectal cancer were excluded from the study. Demographic characteristics including age, gender and body mass index (BMI) and risk factors including diabetes mellitus (DM) and family history were recorded. Data on prognostic factors including the presence of obstruction or perforation at admission, preoperative CEA level, disease stage, tumour invasion grade (T), number of total lymph nodes removed, number of metastatic lymph nodes $(\mathrm{N})$, histopathological type, histologic grade, perineural invasion (PVI), lymphatic invasion (LI), tumour location and presence of surgical margin positivity were obtained from the manual and/or electronic file system. The inadequate number of total lymph nodes removed is considered less than 12. For the determination of survival parameters, the date of diagnosis, relapse and death were also recorded. The interval from diagnosis to the first relapse was defined as disease-free survival (DFS), while OS was defined as the interval from diagnosis to death. The disease stage was determined according to the TNM classification and staging system proposed by the American Joint Committee on Cancer.

The study was approved by the Non-interventional Research Ethics Committee of Dokuz Eylül University.

\section{Statistical Analysis}

Data analysis was performed with SPSS 15.0 software. Descriptive statistics were performed by using mean and standard deviation for normally distributed variables and median and interquartile intervals for normally distributed variables. Chi-square or Fisher's exact tests were used to compare the frequencies between groups. Survival analysis was performed using Kaplan-Meier test, including survival curve graphics that indicate DFS and OS. P value $<0.05$ was accepted as significance level. Log-rank test was used for comparison of survival curves. Prognostic factors with $\mathrm{p}$ value less than 0.05 were also evaluated with Cox-regression test for multivariate analysis.

\section{Results}

Of the 667 patients, 278 were eligible for the study. However, five patients with stage I and 59 patients with stage IV colon cancer and 40 patients with rectal cancer were excluded. Finally, 174 patients with stage II and III colon cancer were included in the study. Moreover, $58 \%$ of the patients were male, the median age (IQR) was 61 (49-68) years and the median BMI (IQR) was $25(22-28) \mathrm{kg} / \mathrm{m}^{2}$. The median OS 
(IQR) was 45 (28-69) months, whereas the median DFS (IQR) was 35 (22-64) months. In this study, 19 (17\%) patients had a family history of colon cancer, while 95 (83\%) patients had no family history. Sixty patients could not be evaluated because of missing data.

Of the 174 patients, 76 (43.7\%) had stage II and 98 (56.4\%) had stage III. The median DFS duration (IQR) was 41.5 (25-69) months in the stage II colon cancer group and 34 (18-62) months in the stage III colon cancer group. The median OS (IQR) was 50.5 (28-75) months in the stage II colon cancer group and 43 (27-68) months in the stage III colon cancer group. The 5-year survival rates including DFS (Figure 1) and OS (Figure 2) for patients with stage II and III colon cancer were not significantly different (Table 1).

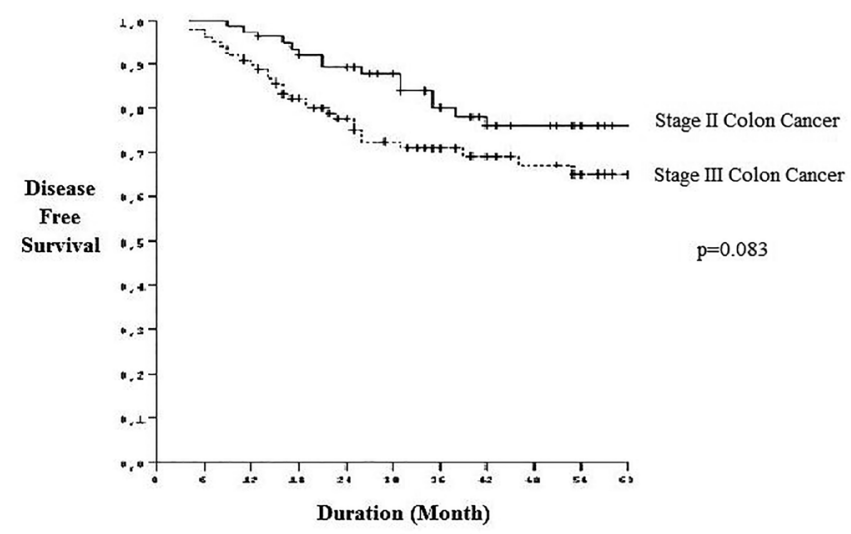

Figure 1. Disease free survival curve of patients with colon cancer according to tumor stage

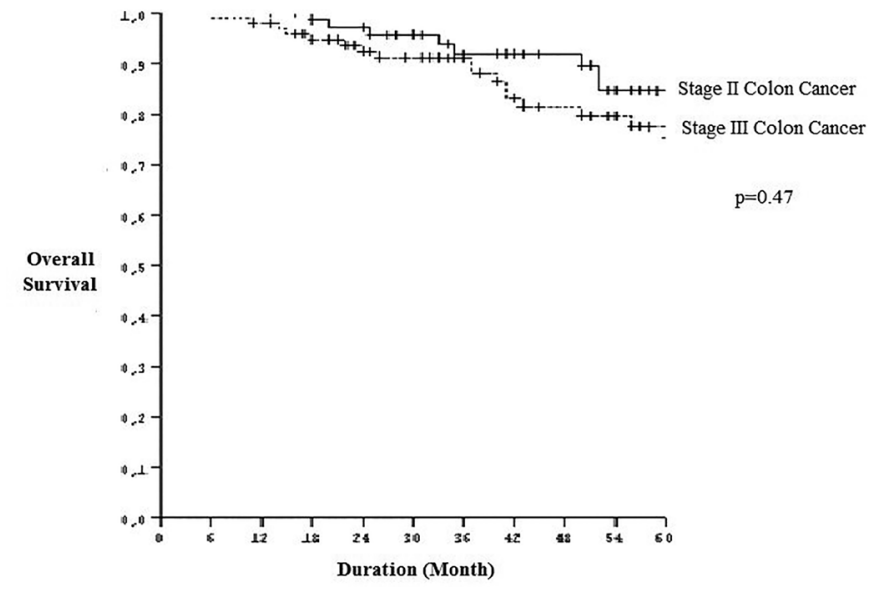

Figure 2. Overall survival curve of patients with colon cancer according to tumor stage
In this study, no effect of age, gender, obesity and DM was observed on survival rates (Table 1). Among the prognostic factors, the number of metastatic lymph nodes, presence of surgical margin positivity, presence of PVI, presence of PNI, histopathological type and tumour location were unrelated with both DFS and OS rates.

The 5-year DFS and OS rates according to the depth of tumour invasion were $62.5 \%$ and $75 \%$ for $\mathrm{T} 2,78.2 \%$ and $89.2 \%$ for T3 and $59.7 \%$ and $65.9 \%$ for T4, respectively. However, the difference was not significant (Table 1).

A significant decrease was found in the survival rate in patients with LI. The 5-year DFS rate was $83.7 \%$ vs $66.8 \%$ in patients without LI and with LI, respectively ( $\mathrm{p}=0.018$ ). The 5-year OS rate was $93.6 \%$ and $67.7 \%$ in patients without LI and with LI, respectively ( $\mathrm{p}=0.022)$, as shown in Table 1 . The 5-year survival durations were significantly longer in the group with $\geq 12$ total lymph nodes removed. In 33 (20\%) patients, <12 lymph nodes were removed, whereas in 133 (80\%) patients, $\geq 12$ lymph nodes were removed. The median DFS (IQR) was 26 (16-51) months in the group with $<12$ and 38 (24-66) months $(\mathrm{p}=0.019)$ in the group with $\geq 12$ lymph nodes removed. The median OS (IQR) was 41 (2868) months in the group with $<12$ and 43 (28-68) months ( $\mathrm{p}=0.004$ ) in the group with $\geq 12$ lymph nodes removed.

In this study, 46 (26.4\%) patients underwent urgent surgery for obstruction or perforation. The median DFS (IQR) was 27 (16-51) months vs 39 (24-67) months in patients with vs without obstruction or perforation $(\mathrm{p}=0.004)$. However, the 5 -year OS rate was not significant between the groups with and without obstruction/perforation $(\mathrm{p}=0.153)$.

Of the 106 patients whose preoperative CEA levels were measured, 65 had normal CEA levels, while 41 had high CEA levels. The 5-year DFS (IQR) were 42 (24-63) months and 34 (18-45) months for patients with normal and high CEA level, respectively $(\mathrm{p}=0.019)$. No significant difference was found between the two groups for the 5-year OS duration ( $\mathrm{p}=0.156$, Table 1).

Factors that had a significant contribution on DFS according to the univariate analysis (including presence of LI, number of lymph nodes removed, obstruction or perforation at admission and preoperative CEA level) were assessed by multivariate analysis. Obstruction or perforation at admission was the only independent prognostic factor ( $\mathrm{p}=0.009$ ). Of the prognostic factors that were significant on OS in the univariate analysis (number of lymph nodes removed and presence of LI), both had independent effect according to the multivariate analysis $(\mathrm{p}=0.004$ and $\mathrm{p}=0.018$, respectively). 
Table 1. Clinical and pathological factors affecting the survival of patients with stage II and III colon cancer

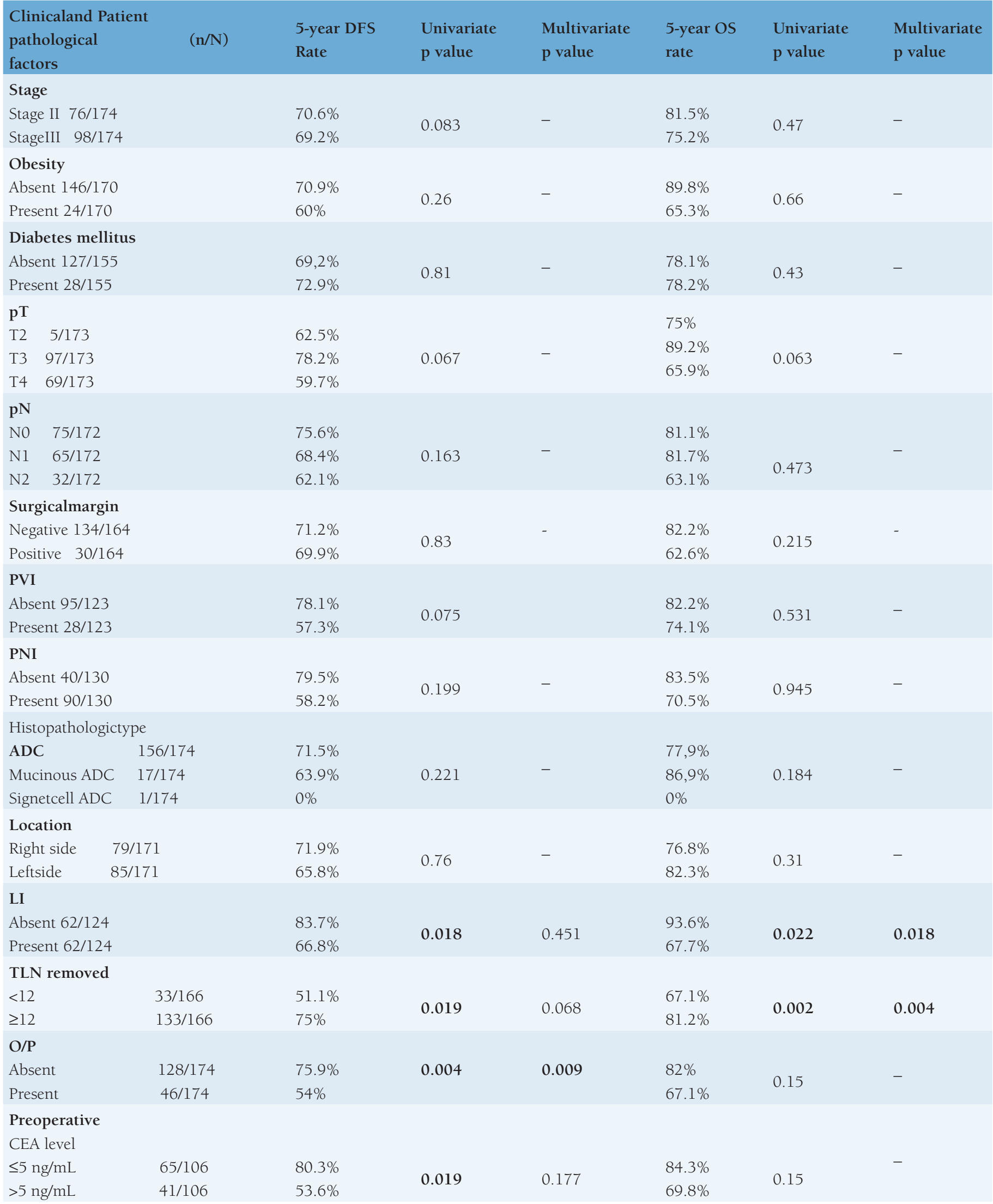

DFS: Disease free survival, OS: Overall survival, pT: Primary tumor, pN: Regional lymp nodes, PVI: Perivascular invasion, PNI: Perineural invasion, ADC: Adenocarcinoma, LI: Lymphatic invasion, TLN: Total lymp nodes, O/P: Obstruction/perforation, CEA: Carcinoembrionic antigen 


\section{Discussion}

Colon cancer is one of the most common malignancies worldwide. Many factors are known to affect survival rates. In this study, according to the survival analysis in patients with stage II and stage III colon cancers, high preoperative CEA level, obstruction or perforation at admission, presence of LI and inadequate number of lymph nodes removed were associated with poor prognosis. While the independent poor prognostic factor for the DFS was obstruction or perforation at admission, they were the inadequate number of lymph nodes removed and the presence of LI for the OS.

Studies have shown a relationship between high CEA level and poor survival. However, some studies do not support this result. ${ }^{69}$ Mixed results were detected in the present study. The high preoperative CEA level was found to be associated with a significant decrease in DFS in the univariate analysis, but it was not true for OS.

Data on the prognosis of colorectal cancers presenting with obstruction are conflicting. ${ }^{10,11,12,13,14}$ Niedzwiecki et al. ${ }^{10}$ demonstrated that presentation with obstruction or perforation had no prognostic effect on survival rates of colon cancers. Similarly, Liu et al. ${ }^{11}$ stated that obstruction did not have any contribution on prognosis in their study of obstructive colon malignancies. However, in the multivariate analysis of the study conducted by the Gastrointestinal Tumor Study Group, obstruction was found to be an important prognostic indicator independent of the Dukes stage. ${ }^{15,16}$ According to the records of Massachusetts Hospital, the 5-year survival rate was lower (31\%) for the obstruction or perforation group undergoing curative surgery in comparison with the control group (59\%). ${ }^{15}$ In this study, the 5-year DFS rates were consistent with literature, i.e. $54 \%$ vs $75.9 \%$ for those with obstruction or perforation compared with those without obstruction or perforation. This difference was also significant in the multivariate analysis. However, the same relationship could not be established for OS rates.

The effect of the presence of LI on prognosis is controversial owing to the varying results reported in previous studies. ${ }^{17,18,19}$ Our data suggest that the presence of LI had a negative effect on both DFS and OS rates in the univariate analysis, but this effect persisted on OS alone in the multivariate analysis.

Despite differing views on the number of lymph nodes that should be removed for adequate and reliable staging, the guidelines state that at least 12 lymph nodes should be removed for histologically accurate evaluation of the lymph nodes. ${ }^{20,21}$ A study stated that the number of removed lymph nodes affects the prognosis regardless of the stage. ${ }^{22}$ In this study, $\geq 12$ lymph nodes removed was a good prognostic factor. Both DFS and OS were significantly longer in patients with $\geq 12$ total lymph nodes removed based on the univariate analysis.

In the multivariate analysis, the total number of lymph nodes removed was determined as an independent prognostic factor for OS, but it was not significant for DFS. The Intergroup (INT-0089) trial evaluated 2,768 patients with lymph node-positive and 648 patients with lymph node-negative colon cancer and concluded that increased number of total lymph nodes removed was associated with prolonged survival. ${ }^{23}$ Inadequate lymph node dissection adversely affected DFS and OS rates in patients with lymph node-positive cancer, whereas it did not significantly contribute to survival in patients with lymph node-negative cancer. The depth of tumour invasion $(\mathrm{T})$ and regional or distant lymph node metastasis of the tumour $(\mathrm{N})$ in the TNM stage are considered the most important prognostic factors. ${ }^{24}$ According to the 119,363 disease data analysis of the Surveillance, Epidemiology and End Results Programme (SEER) between 1991 and 2000, 5-year survival rates in the node-negative group were $93.2 \%, 84.7 \%$ and $72.2 \%$ for patients with T1-2, T3 and T4, respectively. Survival rates were $83.4 \%$ for $\mathrm{T} 1-2$ and $64.1 \%$ for T3-4 in patients with lymph node-positive cancer involving 1-3 lymph nodes. The 5-year survival rates of patients with $\geq 4$ lymph nodes dropped to $44.3 \%$ independent of T. ${ }^{25,26}$ Unexpectedly, survival rates of patients with T2 stage were found to be worse than that of patients with T3 stage in this study. The possible reason was that all patients with $\mathrm{T} 2$ stage had nodepositive (N1) cancer, whereas patients with $\mathrm{T} 3$ stage showed heterogeneity as having node-negative and positive cancer. This suggests that nodal metastasis is the most important factor in prognosis, as shown in SEER. When patients were examined according to lymph node involvement, the 5-year DFS and OS rates were the highest in patients with nodenegative cancer while decreased in patients with lymph node-positive cancer. However, these results were not significant.

The contribution of factors such as gender, age, diabetes, obesity and tumour location to prognosis could not be shown in this study, which was consistent with the results of previous studies. ${ }^{15,27,28,29}$

Histopathology and grade of the tumour, PVI, surgical margin positivity and presence of PNI whose prognostic significance varies according to level of evidence ${ }^{30,31,32}$ were not related with survival in this study. This result, which contradicts with the literature, may be related to the fact that pathologic factors were examined by different pathologists, which may vary over a long period such as 1999-2010. 


\section{Study Limitations}

The main limitations of the study were its retrospective and single-centre design. Another limitation is the lack of a balanced distribution between the groups when patients were grouped according to the presence of prognostic factors.

\section{Conclusion}

In this study, the presence of obstruction or perforation at admission, inadequate number of total lymph nodes removed and the presence of LI were associated with poor prognosis for patients with locally advanced colon cancer. We believe that multicentre and prospective studies are required for more conclusive and reliable results.

\section{Ethics}

Ethics Committee Approval: Dokuz Eylül University Non-interventional Research Ethics Committee (date: 11.08.2011/decision no: 2011/27-07).

Informed Consent: Retrospective study.

Peer-review: Externally peer reviewed.

\section{Authorship Contributions}

Surgical and Medical Practices: Ö.K., A.U.Y., Concept: Ö.K., A.U.Y., Design: Ö.K., A.U.Y., Data Collection or Processing: Ö.K., A.U.Y., Analysis or Interpretation: Ö.K., Y.G., I.B., Literature Search: Ö.K., Y.G., İ.B., Writing: Ö.K.,Y.G., İ.B.

Conflict of Interest: No conflict of interest was declared by the authors.

Financial Disclosure: The authors declared that this study received no financial support.

\section{References}

1. Bray F, Ferlay J, Soerjomataram I, Siegel RL, Torre LA, Jemal A. Global cancer statistics 2018: GLOBOCAN estimates of incidence and mortality worldwide for 36 cancers in 185 countries. CA Cancer J Clin 2018;68:394424

2. Kosmider S, Lipton L. Adjuvant therapies for colorectal cancer. World J Gastroenterol 2007;13:3799-3805.

3. Lowery JT, Ahnen DJ, Schroy PC 3rd, Hampel H, Baxter N, Boland CR, Burt RW, Butterly L, Doerr M, Doroshenk M ,Gregory Feero W, Henrikson N, Ladabaum U, Lieberman D, G McFarland EG, Peterson SK, Raymond M, Jewel Samadder N, Syngal S, Weber TK, Zauber AG, Smith R. Understanding the contribution of family history to colorectal cancer risk and its clinical implications: a state-of-the-science review. Cancer 2016;122:2633-2645

4. Doubeni CA, Laiyemo AO, Major JM, Schootman M, Lian M, Park Y, Graubard BI, Hollenbeck AR, Sinha R. Socioeconomic status and the risk of colorectal cancer: an analysis of more than a half million adults in the National Institutes of Health-AARP Diet and Health Study [published correction appears in cancer. Cancer 2012;118:3636-3644.

5. Vogel JD, Eskicioglu C, Weiser MR, Feingold DL, Steele SR. The American Society of Colon and Rectal Surgeons Clinical Practice Guidelines for the treatment of colon cancer. Dis Colon Rectum 2017;60:999-1017.
6. Konishi T, Shimada Y, Hsu M, Tufts L, Jimenez-Rodriguez R, Cercek A, Yaeger R, Saltz L, Smith J, Nash GM, Guillem JG, Paty PB, GarciaAguilar J, Gonen M. Association of preoperative and postoperative serum carcinoembryonic antigen and colon cancer outcome. JAMA Oncol 2018;4:309-315

7. Hyngstrom JR, Hu CY, Xing Y, Feig BW, Skibber JM, Rodriguez-Bigas MA, Cormier JN, Chang GJ. Clinicopathology and outcomes for mucinous and signet ring colorectal adenocarcinoma: analysis from the National Cancer Data Base. Ann Surg Oncol 2012;19:2814-2821.

8. Siddiqui MRS, Simillis C, Hunter C, Chand M, Bhoday J, Garant A, Vuong T, Artho G, Rasheed S, Tekkis P, Abulafi A-M, Brown G. A meta-analysis comparing the risk of metastases in patients with rectal cancer and MRIdetected extramural vascular invasion (mrEMVI) vs mrEMVI-negative cases. Br J Cancer 2017;116:1513-1519.

9. Ohman U. Prognosis in patients with obstructing colorectal carcinoma. Am J Surg 1982;143:742-747

10. Niedzwiecki D, Bertagnolli MM, Warren RS, Compton CC, Kemeny NE, Benson AB 3rd, Gail Eckhardt S, Alberts S, Porjosh GN, Kerr DJ, Fields A, Rougier P, Pipas JM, Schwartz JH, Atkins J, O'Rourke M, Perry MC, Goldberg RM, Mayer RJ, Colacchio TA. Documenting the natural history of patients with resected stage II adenocarcinoma of the colon after random assignment to adjuvant treatment with edrecolomab or observation: results from CALGB 9581. J Clin Oncol 2011;29:3146-3152.

11. Liu ZH, Li C, Huang NQ, Huang MJ, Peng H, Kang L, Wang J-P. No difference of complete or incomplete left-sided malignant colonic obstruction on both short- and long-term outcomes. Genet Mol Res 2014;13:7965-7978.

12. Mohd Suan MA, Tan WL, Soelar SA, Ismail I, Abu Hassan MR. Intestinal obstruction: predictor of poor prognosis in colorectal carcinoma? Epidemiol Health 2015;37:e2015017

13. Tougeron D, Sickersen G, Mouillet G, Zaanan A, Trouilloud I, Coriat R, Aparicio T, Des Guetz G, Lecaille C, Artru P, Cauchin E, Sefrioui D, Boussaha T, Ferru A, Matysiak-Budnik T, Silvain C, Vernerey D, Bonnetain P. Michel P, Taïeb J, Lecomte T, pAssociation des Gastro-Entérologues Oncologues (AGEO). Predictors of disease-free survival in colorectal cancer with microsatellite instability: An AGEO multicentre study. Eur J Cancer 2015;51:925-934

14. Zucchetti F, Negro F, Matera D, Bolognini S, Mafucci S. Colorectal cancer: obstruction is an independent negative prognostic factor after radical resection. Ann Ital Chir 2002;73:421-425.

15. DeVita VT, LawrenceTS, Rosenberg SA. Devita, Hellman \&Rosenberg's cancer: principles \& practice of oncology. 8th ed. Philadelpia: Lippincott Williams \& Wilkins Publishers, 2008:1232-1285.

16. Steinberg SM, Barkin JS, Kaplan RS, Stablein DM. Prognostic indicators of colon tumors. The Gastrointestinal Tumor Study Group experience. Cancer 1986;57:1866-1870.

17. Lin M, Ma SP, Lin HZ, Ji P, Xie D, Yu JX. Intratumoral as well as peritumoral lymphatic vessel invasion correlates with lymph node metastasis and unfavourable outcome in colorectal cancer. Clin Exp Metastasis 2010;27:123-132

18. Lim SB, Yu CS, Jang SJ, Kim TW, Kim JH, Kim JC. Prognostic significance of lymphovascular invasion in sporadic colorectal cancer. Dis Colon Rectum 2010;53:377-384.

19. Amri R, England J, Bordeianou LG, Berger DL. Risk Stratification in Patients with Stage II Colon Cancer. Ann Surg Oncol 2016;23:3907-3914.

20. Wong JH, Severino R, Honnebier MB, Tom P, Namiki TS. Number of nodes examined and staging accuracy in colorectal carcinoma. J Clin Oncol 1999; 17:2896-2900.

21. de Campos-Lobato LF, Stocchi L, de Sousa JB, Buta M, Lavery IC, Fazio VW, Dietz DW, Kalady MF. Less than 12 nodes in the surgical specimen after total mesorectal excision following neoadjuvant chemoradiation: it means more than you think! Ann Surg Oncol 2013;20:3398-3406. 
22. Baxter NN, Ricciardi R, Simunovic M, Urbach DR, Virnig BA. An evaluation of the relationship between lymph node number and staging in pT3 colon cancer using population-based data. Dis Colon Rectum 2010;53:65-70.

23. Joseph NE, Sigurdson ER, Hanlon AL, Wang H, Mayer RJ, MacDonald JS, Catalano PJ, Haller DG. Accuracy of Determining Nodal Negativity in Colorectal Cancer on the Basis of the Number of Nodes Retrieved on Resection. Ann Surg Oncol 200;10:213-218.

24. Burdy G, Panis Y, Alves A, Nemeth J, Lavergne-Slove A, Valleur P. Identifying patients with T3-T4 node-negative colon cancer at high risk of recurrence. Dis Colon Rectum 2001;44:1682-1688.

25. O'Connell JB, Maggard MA, Ko CY. Colon cancer survival rates with the new American Joint Committee on Cancer sixth edition staging. J Nat Cancer Inst 2004;96:1420-1425.

26. Greene FL, Stewart AK, Norton HJ. A new TNM staging strategy for nodepositive (stage III) colon cancer: an analysis of 50,042 patients. Ann Surg 2002;236:416-421.

27. Burton S, Norman AR, Brown G, Abulafi AM, Swift RI. Predictive poor prognostic factors in colonic carcinoma. Surg Oncol 2006;15:71-78.
28. Loree JM, Pereira AAL, Lam M, Willauer AN, Raghav K, Dasari A, Morris VK, Advani S, Menter DG, Eng C, Shaw J, Broaddus R, Routbort MJ, Liu Y, Morris JS, Luthra R, Meric-Bernstam F, Overman MJ, Maru D, Kopetz S. Classifying Colorectal Cancer by Tumor Location Rather than Sidedness Highlights a Continuum in Mutation Profiles and Consensus Molecular Subtypes. Clin Cancer Res 2018;24:1062-1072

29. Petrelli F, Tomasello G, Borgonovo K, Ghidini M, Turati L, Dallera P, Passalacqua R, Sgroi G, Barni S. Prognostic survival associated with left-sided vs right-sided colon cancer: a systematic review and metaanalysis. JAMA Oncol 2017;3:211-219.

30. Alotaibi AM, Lee JL, Kim J, Lim SB, Yu CS, Kim TW, Kim JH, Kim JC. Prognostic and oncologic significance of perineural invasion in sporadic colorectal cancer. Ann Surg Oncol 2017;24:1626-1634.

31. Benedix F, Kuester D, Meyer F, Lippert H. Influence of mucinous and signet-ring cell differentiation on epidemiological, histological, molecular biological features, and outcome in patients with colorectal carcinoma. Zentralbl Chir 2013;138:427-433.

32. Compton CC. Optimal pathologic staging: defining stage II disease. Clin Cancer Res 2007;13:6862S-6870S. 